\title{
サイクロトロンの視覚的な運転支援環境の実現と評価
}

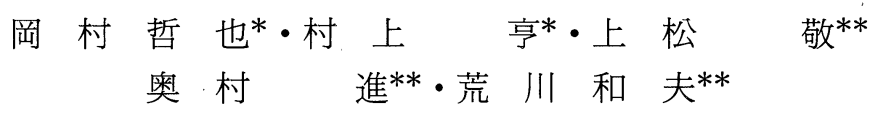

\section{A Visual Assistance Environment for Cyclotron Operation}

\author{
Tetsuya Okamura*, Tohru Murakami*, Takashi Agematsu**, \\ Susumu OKUmURA** and Kazuo ARAKaWA**
}

\begin{abstract}
A computer-based operation system for a cyclotron which assists inexperienced operators has been developed. Cyclotron start-up operations require dozens of adjustable parameters to be finely tuned to maximize extracted beam current. The human interfaces of the system provide a visual environment designed to enhance beam parameter adjustments.

First, the mental model of operators is analyzed. It is supposed to be composed of five partial mental models: beam behavior model, feasible setting regions model, parameter sensitivity model, parameter mutual relation model, and status map model.

Next, based on these models, three visual interfaces are developed, i. e.,

(1) Beam trajectory is rapidly calculated and graphically displayed whenever the operators change the cyclotron parameters.

(2) Feasible setting regions (FSR) of the parameters that satisfy the cyclotron's beam acceptance criteria are indicated.

(3) Search traces, being a historical visual map of beam current values, are superimposed on the FSRs.

Finally, to evaluate system effectiveness, the search time required to reach maximum beam current conditions was measured. In addition, system operability was evaluated using written questionnaires. Results of the experiment showed that the search time to reach specific beam conditions was reduced by approximately $65 \%$ using these interfaces. The written questionnaires survey showed the operators highly evaluate system operability.
\end{abstract}

Key Words : human interface, assistance system, visualization, mental model, cyclotron

\section{1.はじめに}

大規模な機械システムや化学プラントなどの制御シス テムでは，人間を制御ループに含むシステム構成が採ら れることが多い.これは, 非定常のスタートアップ運転

†第 7 回ヒューマンインタフェースシンポジウムで一部発 表 (1991・3)

* 住友重機械工業(株) システム技術研究所，田無市谷戸町 2-4-15

** 日本原子力研究所高崎研究所 高崎市綿貫町 1233

* Systems Engineering Laboratory, Sumitomo Heavy Industries, Ltd., Tanashi

** Takasaki Radiation Chemistry Research Establishment, Japan Atomic Energy Research Institute, Takasaki

(Received January 28, 1992)

(Revised July 24, 1992)
や異常時の緊急運転まで考慮すると完全自動化は容易で はなく，たと元可能でもコストパフォーマンスが現実的 でないことが多いからだと考えられる。このような系で は，オペレータの負担，スタートアップ時間，総合的な 信頼性などがシステムの操作性に依存することが多く, その観点からヒューマンインタフェースの充実が望まれ ている。また，近年は，熟練オペレー夕の不足から未熟 練者でも運転可能なシステムが要求されている．著者ら は大規模システムの一つであるサイクロトロンを対象に

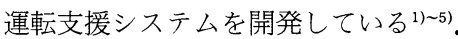
オペレータの経験と勘に頼る作業に，多数の調整パラ メー夕を試行錯誤的に調整し，最適運転条件をみつける 作業が含まれることがよくある。つまり，調整パラメー 夕を軸とする多次元の操作空間内をオペレー夕が探索 し，最適設定值を求めるわけである。サイクロトロンの 
場合は, 多数の機器の設定值を調整して引出されるビー ム電流を最大にするというビーム調整がこの作業に相当 する.

現状の加速器ではすべての機器を遠隔操作できるの で, 初期のシステムより操作性は良くなっている。また, 閉ループ制御系により部分的には自動化も進みつつあ る.しかし, 人間と機械のインタフェースとしての切り 口は従来と同様に, 機器設定值とビーム電流值であるこ とが多く, 計算機側はそれ以上の情報をあまりオペレー 夕に提供していない.完全自動化に至るステップとして, 人間が能力を十分に発揮できるように機械が補助する運 転支援システムが要望されている.

近年, 運転支援システムとして, 故障診断や運転ガイ ダンスなど AI 技術を適用したエキスパートシステムの 研究が盛んであり, 加速器の制御システムへの適用例も 少なくない( ${ }^{6,7)}$. その多くは物理的知識や熟練オペレー夕 の経験則を IF-THEN ルールとして記述し, それらを検 索, 推論してガイダンスを出力するものであり, ルール 化の比較的容易な分野では有効なツールとなっている. このようなルールベースシステムでは, 熟練者の意識下 の知識をいかに引き出すかという知識獲得の問題や, IF 節に記述される運転状況をいかに判断するかという状況 認識の問題が課題として残されている, また, 言語メッ セージとして正確なガイダンスが与えられたとしても, 調整などスキルベースの作業では丹念にメッセージを読 んでつぎの行動を計画するというステップがとられるこ とは稀であり, より視覚的で直感的なガイダンス提示法 が求められている.

そこで, 多変数操作空間における最適値探索作業を支 援するために，ビーム軌道の状態やおよその設定值の範 囲などをオペレータに表示する視覚的な運転支援環境を 開発した.この環境の特徵は, 従来のエキスパートシス テム型の運動支援システムのようにシステム側がオぺ レータに対して一方的に指示を与えるのではなく, オぺ レータ自身が操作しながら発見的に対象システムの振舞 いに関する理解を深めていく環境であることである、こ のシステムの設計にあたってまず，オペレータの思考を 分析し, メンタルモデルが五つの部分モデルからなるこ とを示した。これらに基づき視覚的な運転支援環境にお けるヒューマンインタフェースとして, 軌道シミュレー タを用いた軌道表示インタフェース, 調整パラメータの 設定可能領域 (以後, FSR: Feasible Setting Regions と 呼ぶ)を表示するインタフェース, それに調整の評価量で あるビーム電流值の分布を操作履歴として表示するイン タフェースを開発した.このなかで最も特徴的な機能は, パラメータの設定できる範囲を実時間に表示する FSR
表示である.これは設定操作を行う環境と同一の座標系 でガイダンス情報を図を用いて表現するものであり，才 ペレータは高度な知的判断に依らず反射的にガイダンス を行動に結び付けることができる，また，推奨設定值が 領域として示されるため, パラメータの感度や干渉度合 など調整に必要な傾向を読みとることもできる。

最後に, 実システムでの調整時間の測定と操作感覚の アンケート調査により, これらの機能を評価し, その有 効性の考察を行う.

\section{2. サイクロトロンの構造とビーム調整}

サイクロトロンは，一様磁場中における荷電粒子の円 運動の周期がその速度に依らず一定であるという事実 と，その周期に同期した高周波電場による加速という原 理に基づいており，その全体は Fig. 1(a)のような構造 である。

ビーム調整は 30〜 50 の機器設定值を最適化して, 出力 のビーム電流を最大にする作業であるが, サイクロトロ ンの入りロから出口までのビーム通路には開口が数 $\mathrm{mm}$ のチャンネルが数カ所あり, ビーム調整はそこでの 損失が小さくなる軌道を探すことだともいえる．軌道を 直接見ることができない環境で，ビーム電流值だけを頼 りに最適軌道を探索するところに針に糸を通すような調 整のむずかしさがある．実際の調整では，すべてのパラ メータをむやみに操作するのではなく, ビームの流れに 沿ったいくつかの調整ブロックを順次最適化する，本論 文では以下の三つの調整ブロックを取り上げる.

Fig. 1(b) に垂直入射ブロックの構造を示すが，この ブロックは, 外部から入射されたビームを加速平面に導 くまでの区間である.このブロックの調整目標は, ブロッ ク終端のインフレクタと呼ばれる狭いチャンネルに損失 なくビームを通すことであり, そのために, 四つの磁気 レンズ $\mathrm{A}, \mathrm{B}, \mathrm{C}, \mathrm{D}$ の電流値, つまり, 焦点距離を調整 してビームを絞り込むという調整を行っている. 調整時 の評価量は，インフレクタ下流のビーム電流センサでの 検出值であり，それを最大にすればよい.

Fig. 1(c) は中心領域ブロックであり, サイクロトロ ン中心にあるインフレクタから二つのスリットまでの ビーム軌道を調整するブロックで, 加速空洞内での初期 軌道を決める，スリットの本来の役割は，ビームと加速 電界の位相差に起因するビームの拡がりを除去してビー ム位相幅を制限することであるが，初期軌道を所定の半 径に通すための照準器の役割もになっている. したがつ てスリットの間をうまく通すことがこのブロックの調整 目標となる. 調整パラメータは加速電圧 (ディー電圧), 中心磁場, ビーム入射位相であり, それらを調整して, 


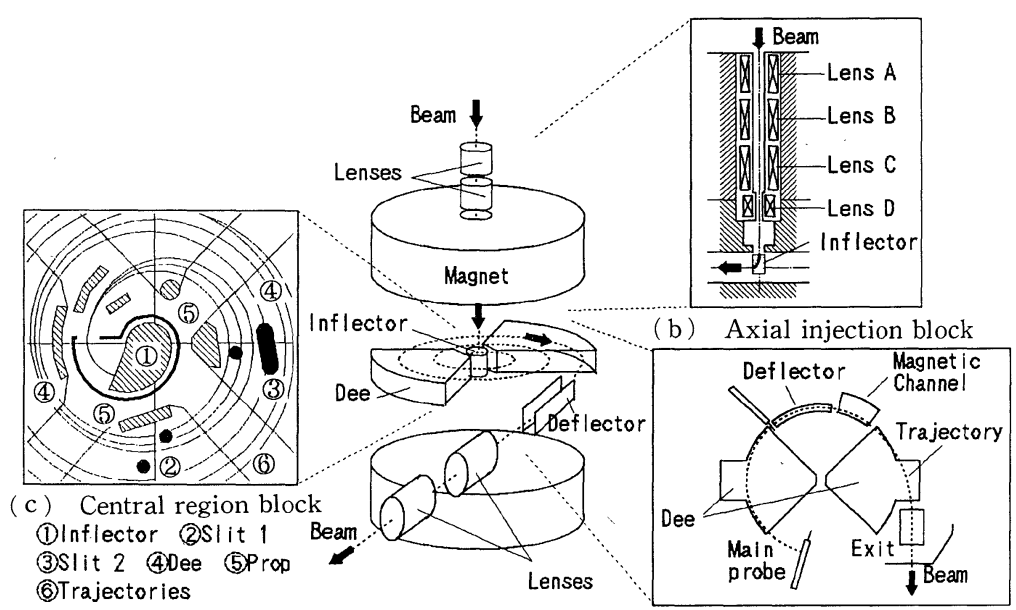

(a) Cyclotron system

(d) Extraction block

Fig. 1 Schematic diagram of a cyclotron

スリット下流でのビーム電流值を最大にする.

加速ビームを加速箱から外部に取り出すためのブロッ クが Fig. 1(d)に示した引出しブロックであり，粒子に 外向きの電磁力を与えるためのデフレクタと磁気チャン ネルの間にビームを通して, 出口までビームを導く。こ のブロックの調整パラメータはデフレクタ電圧と磁場 チャンネルのコイル電流である。また, 評価量はサイク ロトロン出ロのビーム電流値である.

\section{3. オペレータのメンタルモデル}

熟練度の高いオペレータが未熟練者に比べて上手に対 象を操作できるのは, 自らの経験やマニュアルなどの知 識から対象機械に関するメンタルモデルをすでに形成し ており,それに基づいて操作を行うためだと考えられる。 良いヒューマンインタフェースとは，操作対象をブラッ クボックス化するのではなく，逆に未熟練者がシステム を理解して適切なメンタルモデルを形成するのを支援す るものでなくてはならないと指摘されている ${ }^{8) \sim 10)}$. そこ で, ビーム調整のためのインタフェースを設計するにあ たって，まず，熟練オペレータがぞのようなメンタルモ デルをもって対象を操作しているかを分析した。

分析方法のフローチャートをFig. 2 に示す.まず, 害 際の現場に立ち会ってオペレータの操作を観察し, その 動作をビデオに撮り発話を録音した。同時に調整作業を 妨げない程度の質疑応答も作業中に行った。さらに, 録 画や録音からのプロトコル解析に基づき，同時もしくは 連続して操作されるパラメー夕群を抽出して調整手順を 整理した ${ }^{11)}$.

つぎに,これらの結果や調整中の発話の説明を求める

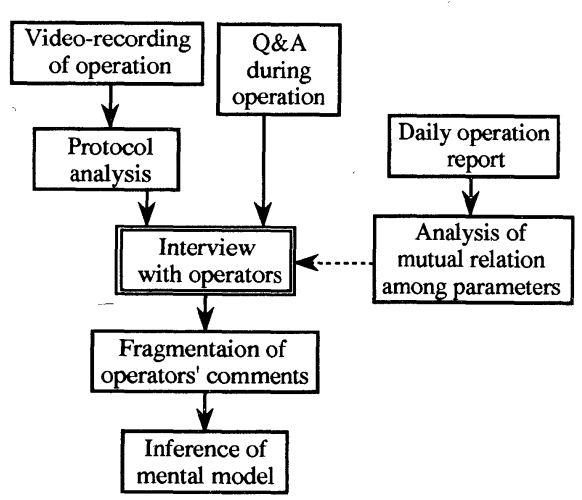

Fig. 2 Flowchart for analysis of operator's mental model

形で, どのような効果を期待してその操作手順をとった か, そのときのイメージはどのようなものか, 同時もしく は連続して操作するパラメータ間の関係は何かなどの項 目についてヒアリングを行った。 なお，あらかじめ数力 月にわたる運転記録より調整パラメータ間の相関関係や 干渉度合を調べて抢き ${ }^{12)}$ ，ヒアリングの参考データとし て利用した。最後に, 調整中の発話やヒアリング時の発 言をひとまず断片的なセンテンスに分け，それらをオぺ レータの想起しているイメージの観点から分類した。

以上の分析の結果, オペレータは以下の五つのメンタ ルモデルをもっていると推測できた. 各モデルを代表す る発話の例もあわせて示す。

[モデル 1] 操作対象の物理的な振舞い, メカニズム に関するモデル. サイクロトロンでの操作対象はビーム 軌道であるが，熟練オペレー夕は調整パラメータにより 軌道がどのように変化するかを推測できる，たとえば， 
コイル電流を増やすと磁場が強くなり，その結果，軌道 半径が小さくなるという具合いである。具体的な発話と しては，「加速電圧を上げて軌道を外に動かす」というよ うな軌道に関するものが挙げられる。

[モデル 2］ 調整パラメータの FSRに関するモデル. 熟練オペレータは，試行錯誤的な探索を行う場合でも， およそどの範囲で設定值を調整すれば良いかを経験的に 把握していることが，「多分 $30 \mathrm{~A}$ 以上だよ」というよう な発言に表われている。これは，多次元の操作空間にお ける FSR をイメージしていることになる。

[モデル 3］調整パラメータの感度に関するモデル。 設整時には，「このパラメータは効く」というような発言 が聞かれる。この判断ができるのは，パラメータのビー 厶電流に対する感度のモデルが形成されているからだと 考えられる。

[モデル 4] 調整パラメータの干渉度合に関するモデ ル．オペレータは，たとえば加速電圧を大きくしても， 磁場を小さくしてもビームの軌道半径は大きくなるとい う知識をもっている。これは，二つ以上のパラータが操 作対象に対して相乗的に影響するか，相殺的か，それと もほとんど無関係かという干渉度合に関するモデルを もっていることを示している.「この二つは相関が強いか ら同時に調整する」は代表的な発言である。

[モデル 5］評価量の操作空間における分布のモデ ル．最適設定値の探索においては，対象のある状態量を 評価量として, その最大值/最小值を探索する。サイクロ トロンの場合はビーム電流值がそれに当たる。オペレー 夕は自らの探索履歴を記憶し，操作空間内での評価量の 分布マップをイメージして，最適值を探索している。 「さっきのところがいちばん良かった」などはこのモデル に関する発言である。

\section{4. ビーム軌道調整のための視覚的な運転支援環境}

\section{1 支援環境のシステム構成}

探索作業を支援するヒューマンインタフェースとし て，メンタルモデルを視覚的に表現し可視化するような 支援環境を設計する．五つのメンタルモデルの特徵を考 察すると，モデル 1 はビーム軌道を幾何空間の中でイ メージしたものであり，そのほかは設定值を座標軸とす る操作空間における様々な属性に関するモデルである. したがってインタフェースとしても，軌道を幾何学的な 座標系で表現したビーム軌道表示と，調整パラメータを 座標軸としたほかのモデルの表示の 2 種類を用意する。 ビーム軌道表示は，実時間で軌道の全貌を計測できない ので, 次善の策として機器設計において実績のある軌道 シミュレーションを用いることにより実現する。

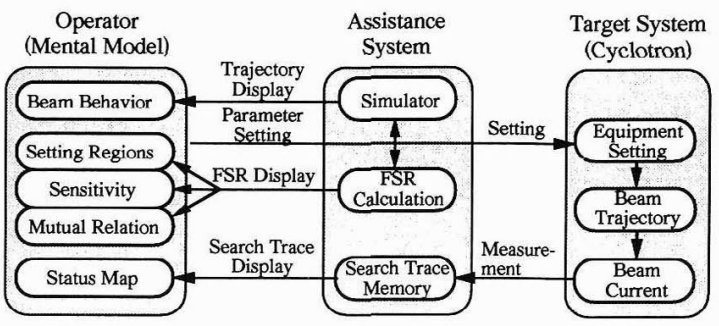

Fig. 3 Structure of the visual assistance system for cyclotron operation

つぎに，モデル 2 ～ 4 とモデル 5 を比較すると，前者は 設定前のフィードフォワード的なモデルであるのに対 し，後者は設定後にその効果を確認するフィードバック に関するモデルである。後で議論するがこれらは FSR 表示，操作履歴表示として実現する。フィードフォワー ド的なガイダンスとフィードバック情報を同一の座標系 で視覚的に表現することにより，才ペレータは双方の情 報を一目で理解でき，反射的にガイダンスを行動に結び 付けられるというのがこのインタフェースの利点であ る、以上を整理すると，この支援環境は以下の三つのイ ンタフェースからなる。

(1) 軌道シミュレータによるビーム軌道のグラフィッ ク表示インタフェース。これは実際には見ることのでき ないビーム軌道を表示することにより，あたかも直接 ビームを操作しているかのような感覚をオペレータに与 えるものである。

(2) 操作空間内における調整パラメータの FSRをリ アルタイムに計算，表示するインタフェース。これはパ ラメータの設定可能な領域，つまり最適值の存在する可 能性の高い領域を算出しそれを表示するもので，探索領 域を限定することができる。

(3) 調整の評価量であるビーム電流值の分布を操作履 歴として表示するインタフェース。これによりオペレー 夕は，操作対象の状態量の操作空間内における分布を大 局的に判断でき，最適設定点を同定しやすくなる.

このシステムの全体像をオペレータや操作対象との関 係においてまとめたのが Fig. 3である.オペレータがサ イクロトロンの機器を設定し，その応答であるビーム電 流值を確認してから，再度設定するという操作ループの なかに支援システムが組み込まれ，制御対象からオぺ レータに与えられる情報をシステムが補うという構造に なっている。また，支援システムからオペレータへの出 力情報はメンタルモデルと対応していることもわかる。

\section{2 ビーム軌道表示インタフェース}

オペレータがモデル 1 を形成するのを支援する一つの 方法は，オペレータが操作対象を視賞的に現実感を伴っ 
て見，それを直接操作しているように感じ，その変化を 常に把握できる環境，いわゆるWYSIWYG (What You See Is What You Get)の環境を提供することである ${ }^{13)}$.

操作対象であるビーム軌道を実時間で計測し表示する ことができれば,そのような環境を作ることができるが， 実際にはビーム軌道の全貌を計測することは困難であ る。そこで，ビーム軌道の数式モデルを用いて，オペレー タの操作ごとにビーム軌道を計算し，表示するインタ フェースを開発した。

Fig. 4(a)が，垂直入射ブロックにおけるビーム包絡 線の表示例である．赤線は線対称のビーム包絡線の片側 を表示したもので，調整パラメー夕を変更するたびに重 畳して描かれる。ビームは画面右端から入射し，左端の インフレクタに絞り込まれる。このビーム包絡線はビー

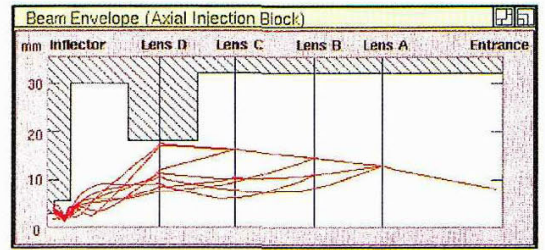

(a) Axial injection block. Red lines are envelopes of beams in different conditions

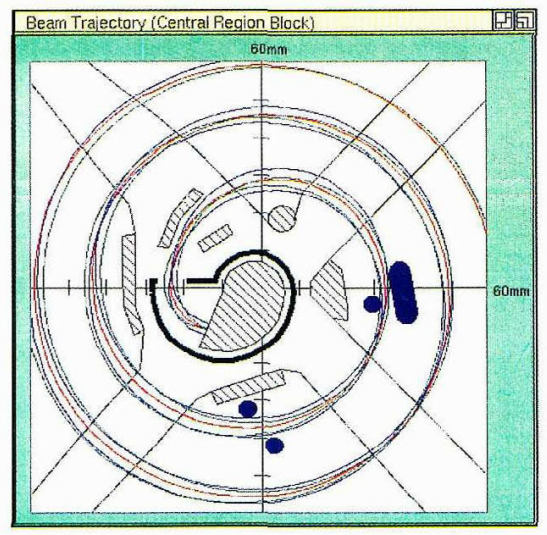

(b) Central region block. Red line is a central trajectory, and blue lines are trajectories with different injection angle

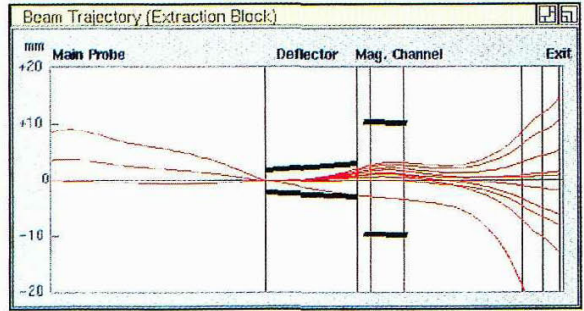

(c) Extraction block

Fig. 4 Examples of beam trajectory display
ム光学的に定義された伝達行列を順次掛け合せることに より求めることができる14)。

Fig. 4(b) は中心領域ブロックにおけるビーム軌道の 表示例である.ビーム軌道は荷電粒子の運動方程式を数 値積分法の一種である Runge-Kutta-Gill 法(RKG 法) によって逐次的に解いて求める15). また，このインタ フェースには，ビーム位相幅を変更するためにスリット が操作された場合に，画面上のスリット位置がアニメー ション的に変更されるという機器配置の動的表示機能も 含まれる。

Fig. 4 (c) に引出しブロックでの表示例を示す. 赤線 は, 理想軌道を横軸としてそれからの軌道の変位を条件 ごとに表示したものである.軌道計算は, 中心領域ブロッ クと同様に RKG 法による ${ }^{16)}$.また，この画面でもデフレ クタや磁気チャンネルの配置はその調整にあわせて動的 に表示される。

軌道表示インタフェースでは，オペレータが調整パラ メー夕を変更するたびにビーム包絡線やビーム軌道を計 算し，以前の結果に重畳表示している。これにより，軌 道の変化量を確認でき，数式モデルに誤差が多少あって も，オペレータは少なくとも定性的には自らの操作が ビームにどのような作用を及ぼしたかを把握できる。つ まり，有効なフィードバック情報となっている。また， 機器配㯰の動的表示も視覚的なフィードバックである.

このような操作環境は, CAIに扔けるマイクロワール ド17)と同様に試行錯誤に基づく発見的な学習環境を才 ペレータに提供しているとみなすこともできる。した がって，オペレー夕は調整作業を行うと同時に，対象に 対する理解を深め，モデル 1 を形成していくことができ る.

\subsection{FSR 表示によるオペレータガイダンス}

調整パラメータのおよその調整範囲に関するメンタル モデル (モデル 2 )のイメージを可視化することにより， 未熟練者に対して探索範囲の指標を与えることができ る. そこで, 軌道の数式モデルの逆問題を解いて, FSR を求め表示するインタフェースを開発した。

多次元の操作空間内で最適設定值を探索するための, 具体的な操作インタフェースは, Fig. 5 に示すように多 次元空間を 2 次元平面でスライスした操作平面を複数表 示し，その上をマウスでポイントすることにより，実際 の機器に設定值が送られるというものである。操作平面 において，各軸は調整パラメータの設定值である。

操作平面内の黄色の領域が FSR であるが, その意味 をFig. 5 左側の操作平面で説明する.この FSR は, 調整 パラメータととDの值が現在の值から変更されない限 り,この FSR 内にパラメータAと B の設定値を設定す 


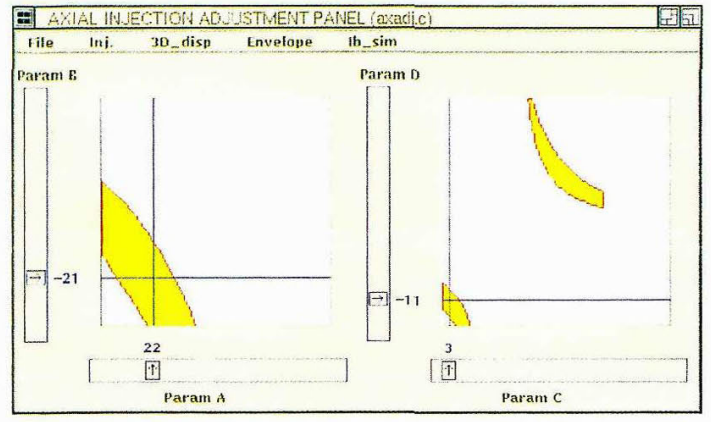

Fig. 5 Adjustment planes and FSR display

れば，少なくとも数式モデルでは，ビームは目標のチャ ンネルを通過し, 調整目標を達成することを示している. ここでの調整目標は, 調整ブロックごとに設定されるが, 垂直入射ブロックではビームがインフレクタを通過する こと, 中心領域ブロックではビーム中心軌道がスリット を通ること, 引出しプロックでは中心軌道が出口を通過 することである。つまり，FSR は現在の動作点における 計算上の設定值の許容領域である.

FSR を求めるには, 操作平面内の各点においてビーム が調整目標を満足するかどうかを判定しなくてはならな いが，総当り方式では計算時間が長くなり，実時間性を 損なう。ここでは，黄金分割探索法と境界線追跡法を用 いた高速の FSR 算出アルゴリズムを用いた ${ }^{3)}$ 。た，中 心領域ブロックの FSR の算出に扔いては, 非線形モデ リング法の一つである GMDH 法を用いてあらかじめ ビーム軌道の多項式近似式を求めておき，ビーム調整時 にはそれを用いることにより高速化をはかっている4． 引出しブロックにおいても軌道計算の線形近似により高 速化している。ここでの実時間とは，人間にあまり待つ という感じさせない 1 秒以内の再計算と再表示である.

FSR は数式モデルに基づいているため, モデルの近似 誤差や磁場や電場の推定誤差などにより, 実システムと は正確には一致しない. したがって, FSR 内に設定して も必ずビームが通るとはいえず，オペレータによる試行 錯誤探索は残るが，この表示により探索範囲はこの領域 の近傍に限定されるため, 探索作業の収束が早くなるこ とが期待できる。 また，モデル 2 のイメージを直接的に 見ることができるため, メンタルモデルの形成が促進さ れると考えられる。

FSR の形状はモデル 3 およびモデル 4 に対応する情 報も含んでいる。まず，モデル 3 の調整パラメータの感 度については現在の設定值を示すクロスカーソルがおの おのの軸方向でFSR と交わる長さによって示される. この交差長が長ければパラメータを大きく変化させても
FSR 内に留まるので感度は低いといえる.逆に短ければ 感度は高い.つぎに，モデル 4 のパラメータ間の干渉度 合についてはFSR の傾きで示される。すなわち, Fig. 5 左側のように右下がりの FSR なら，パラメータ A を増 やす操作はパラメータ B を減らす操作と同様の効果を もつ，つまり，二つのパラメータの軌道に対する作用は 同じ方向であるので相乗的である。また，逆に右上がり であれば相殺的であるといえる。

\section{4 操作履歴の表示インタフェース}

オペレータは自らの操作によって操作対象の状態がど のように変化したかを常にモニタし，それが望ましい状 態に近づいたかどうかを評価している。その際に重要な のは，毎回の操作と応答だけではなく，過去にどのよう な経過で探索を行ったかという履歴である。なぜなら， その操作と応答の履歴に基づいて操作空間における評価 量の分布のイメージ(モデル 5 )を作り上げていると考光 られるからである。

サイクロトロンの場合には，オペレータの指示した操 作平面上の位置とその位置でのビーム電流值を逐次記録 したのが, 操作履歴である.そこで, Fig. 6 に示すように, 設定值を変更するたびにその值に対応する操作平面上の 位置に，ビーム電流值を色表現したドットを表示するイ ンタフェースを開発した。このように操作と応答を画面 上に記録することにより，オペレータは，評価量(ビーム 電流值)の分布を多数のドットからなる色領域として大 局的に把握することができる。操作履歴はFSRに重ね て表示されるため, 色領域の分布と FSRの差，つまり， 実システムと数式モデルの差をオぺレータは視覚的に認 識し，かつ補正しながら，限られた領域において試行錯 誤探索を行うことができる.

Fig. 6 は実システムで記録した例であるが，FSR と最 適設定值の間に差があることがわかる。この図は調整範 囲の一部分の拡大図であり，カラースケールもビーム電 流値の狭い範囲を拡大して割り当てているため, 誤差が 大きいとの印象を受けるが，実際には FSR 内の黄色の

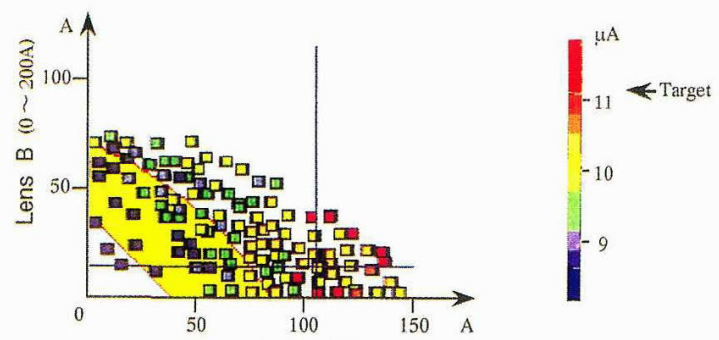
Lens $A(0 \sim 200 A)$

Fig. 6 Search trace display, being a historical visual map of measured beam current values represented by various colored dots, superimposed on the FSR 
点では目標の $90 \%$ を達成しており, FSR は十分に最適 值近傍を示しているといえる．また，カラードットの分 布が FSRのように単純ではなく，多くの凹凸があるよ うに見えるのは，イオン源から出力されるビーム電流が 時間的に微妙に変動しているからである。オペレー夕は このよう変動を巧みにフィルタリングして最大值を見つ けているが，それを自動化することは容易ではないこと も，人間を介入させる方式にした理由である.

B. Shneiderman は，8項目のインタフェース設計の 原則を示している18)が，その中で有益なフィードバック の提供と短期記憶の負担軽減を挙げている。提案したイ ンタフェースは, メンタルモデルの可視化だけでなく, この二つの原則を満たしている。つまり，オペレータの 操作に対して，ただちに結果がポイントした位置に表示 されるので, 視覚的なフィードバックを構成している. また，操作履歴を視覚的に表示することは人間の短期記 憶を補っており，探索における不都合な事態，たとえば， 同じような設定值を何度も試してしまう堂々巡りや，少 し前の設定値に戻せないという事態を防ぐ効果がある.

\section{5. 評価実験と考察}

評価実験を, 日本原子力研究所高崎研究所の高エネル ギイオン照射装置 (930 型 AVF サイクロトロン) ${ }^{19)}$ に掠 いて行った。評価方法は, 調整時間の測定と操作感覚の アンケート調査である.

\section{1 調整時間に関する評価と考察}

インタフェースの違いによる調整時間の短縮の効果を 調べるために, 以下の三つの調整モードについて, 目標 ビーム電流值に達するまでの調整時間を計測した。

Mode 1 : Fig. 7 ( a ) のような従来型のコンソールで調 整する，つまり，ビーム電流計を見ながら，四つのロー タリエンコーダで設定值を変更する．このモードでは当 然 FSR，操作履歴のいずれも表示されない.

Mode 2：Fig. 7( b )のように操作平面を表示し，その上 をマウスでポイントすることにより,設定值を変更する. ビーム電流值はカラードットとして操作平面上に表示さ
れ，それが探索履歴として残る。ただし，このモードで はFSR は表示されない。

Mode 3 : Mode 2 と同じ操作環境に加えて FSR も同様 に表示される(Fig. 7(c)).

被験者は熟練者 1 名, 訓練を受けた者 4 名, ほとんど 素人 4 名の計 9 名のオペレータである. 目標ビーム電流 值は，あらかじめ熟練オペレータが調整したときの最大 ビーム電流值の $95 \%$ とした。実験は最適設定值から故意 にずらした設定值から被験者による探索を開始し，ビー 厶電流值が目標值に到達するまでの時間を各 Mode に ついて 1 回ずつ計測した. 調整順序は Mode 1, 2, 3 の順 で行ったが,慣れや記憶による影響を少なくするために， 設定值表示を隠し試行ごとにエンコーダ割当や操作平面 の軸配置を変更した.また,できる限り実験条件を合せて 比較を容易にするために，この実験は垂直入射ブロック の調整で行い,パラメータは四つの磁気レンズに限った. ただし，軌道表示インタフェースは使用しなかった。

評価実験の結果として, 各人の調整時間とその中央値 をTable 1 に示す. 中央値を採用したのは平均值に比心゙ て極端な值の影響を受けにくいからである ${ }^{20)}$. 数值は各 人の Mode 1 での調整時間で正規化してある.

Mode 2 での調整時間は Mode 1 に比べて $20 \%$ 以上短 縮された. Mode 1 より調整時間の長い被験者は 1 人だ けであり，その差も小さいことから，ほぼすべての被験 者にとって Mode 1 より Mode 2 のほうが操作性が良く なったといえる.なお，この 1 人は唯一の熟練者であり, 従来のコンソールに習熟していたためにこのような結果 になったと考えられる．操作性向上の理由としては操作 履歴表示とマウス操作が考えられるが，アンケートでは 二つとも有効であるとの回答が多く相乗的な効果によっ て調整時間が短縮されたものと考えられる.

Mode 3 での調整時間は Mode 1 と比べて 35\%以上, Mode 2 と比べても 15\%以上減少した。評価実験を行っ た状況では最適設定值は FSR の外側にあり，オペレー 夕にとっては悪い条件下での実験であったにもかかわら ず，FSR 内に設定するだけで $70 \sim 80 \%$ と比較的多くの

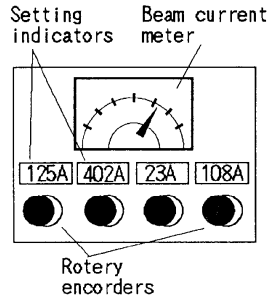

(a) Mode 1

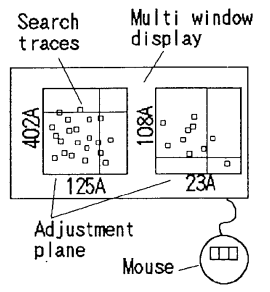

(b) Mode 2

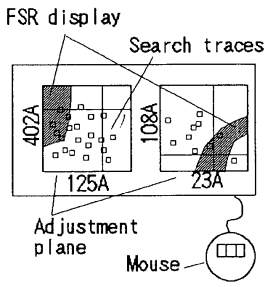

(c) Mode 3

Fig. 7 Schematic diagram of evaluated interfaces 
Table 1 Summary of search times using three inteface modes

\begin{tabular}{|c|c|c|c|c|c|}
\hline Operator & Level $^{a}$ & Mode $1^{\mathrm{b}}$ & (real time) & Mode $2^{c}$ & Mode $3^{\circ}$ \\
\hline 1 & $\mathrm{E}$ & 1.0 & $(203 \mathrm{sec})$ & 1.07 & 0.59 \\
\hline 2 & $\mathrm{~T}$ & 1.0 & $(210$ & 0.76 & 0.86 \\
\hline 3 & $\mathrm{~T}$ & 1.0 & $(207$ & 0.68 & 0.63 \\
\hline 4 & $\mathrm{~T}$ & 1.0 & $(350$ & 0.97 & 0.73 \\
\hline 5 & $\mathrm{~T}$ & 1.0 & $(260$ & 0.67 & 0.46 \\
\hline 6 & $\mathrm{~N}$ & 1.0 & $(130$ & 0.92 & 0.85 \\
\hline 7 & $\mathrm{~N}$ & 1.0 & $(410$ & 0.95 & 0.80 \\
\hline 8 & $\mathrm{~N}$ & 1.0 & $(605$ & 0.65 & 0.42 \\
\hline 9 & $\mathrm{~N}$ & 1.0 & $(640$ & 0.47 & 0.34 \\
\hline \multicolumn{2}{|c|}{ Median } & 1.0 & & 0.76 & 0.63 \\
\hline
\end{tabular}

${ }^{a}$ Level : E ; Expert, $\mathrm{T}$; Trainee, $\mathrm{N}$; Novice.

${ }^{\mathrm{b}}$ Mode 1 : Using the existing console with dials and a current meter.

${ }^{c}$ Mode 2 : Using the assistance system without the FSR display.

${ }^{d}$ Mode 3 : Using the full assistance system.

ビーム電流值が得られ，目標ビーム電流值まで速やかに 到達することができた. つまり, FSR 内に設定すること により，たとえ最適設定值がそのなかになくても最適值 の近傍に達することができるので, 探索作業の初期段階 において FSR 表示のメリットは大きいと評価できる.

つぎに, Mode 3 の実験において観測された興味深い 現象について考察する. 被験者には目標ビーム電流に達 した後も探索を続けて最大電流值を探すように要請し た．実際の調整作業においては, 調整ブロック間のバラ ンスをとりながら最適設定值を求めるので個々のブロッ クで厳密に最大值をみつけることはあまり意味がない が，ここでは支援機能の評価を行うためこのように要請 した. Mode 1, Mode 2 では全員が目標值到達後, 短時 間のうちに最大電流值に達している. また, Mode 3 にお いても 9 人中 6 人はやはり短時間で最大值に達している が, オペレータ 2, 3, 5 については Mode 1 に比べてそれ ぞれ $1.76,1.74,4.40$ と調整時間が長くなった.この理 由を検討するために, 各人の操作状況を録画から調べた ところ,この 3 人の被験者は, いずれも FSRの内部のみ を詳細に探索した結果, FSR から少しはずれた最大值を みつけられなかったことがわかった。つまり, FSRが多 少不確かなガイダンス情報なのに, 境界の明確な領域と して表示したために, FSR の外側を探索することに対す る心理的な障壁になったと考えられる。これと同様の現 象は心理実験における “9 点問題” として指摘されてい る ${ }^{21)}$.これは,「 3 個ずつ 3 列等間隔に並んだ 9 点をすべ て通過する 4 本の直線を一筆で描け」というもので, 9 点を囲む正方形内だけで考えていると解けないが，その 外側まで直線を延ばせば解けるという問題である。つま
り，境界を強く意識することが正解への到達を阻害する 可能性があるという点でFSRの場合と類似している.

しかし，このようなオペレータでも FSR と最適值の 間に不一致があることをアドバイスすると容易に最大值 に達したことから，この事実を認識していれば実際の作 業において混乱はないと考えられる。また，実システム との差が問題になるのは, 最適值をかなり絞り込んだ最 終的な局所探索の局面においてであるが，その時点では オペレータの注意は履歴表示を参考にして最適值の見当 をつけることに向けられており, FSR の誤差によりオぺ レータをミスリードするというデメリットは小さい.こ れは 3 人以外のオペレータが，初期の大域的探索におい てはFSR を参照して速やかに最大值近傍まで達し, そ こからの局所的探索においてはFSRに重きを置かずに 試行錯誤的に最大值を探したため短時間で探索を完了し ていたことからも襄付けられる。

積極的な対策としては, FSR の境界を等高線表示にし たりぼかしたりするなどの方法により，完全に正確なガ イダンス情報ではないことをユーザに直感的に認識させ るような工夫が考えられる。これは「〜らしい」という 言語表現に相当する図的表現にあたる。また，実システ ムにおける探索履歴から FSR との誤差方向を推測し, 探索方向についてのガイダンスをオペレータに示すこと も有効な対策であろう。

\section{2 アンケートによる操作性の評価}

アンケート調査とインタビューにより，定性的ではあ るが本システムによる操作性の向上度合を評価した，オ ペレータには，すべての機能を自由に操作してもらった 後に, (1) ビーム軌道表示, (2) FSR 表示, (3) 操作履歴表 示, (4) 機器配置の動的表示, (5) マウスによる設定につ いて，その有効性を 5 段階 (5: 有効性が大きい, 4 : 有効 である, 3：どちらともいえない, 2：あまり有効でない, 1 : 全く有効でない)で評価してもらった．回答者は 7 名 である。

Table 2 に各機能に対する評価值の平均值と度数を示 すが,すべての機能について 4.0 4.7 と高い評価值が得 られた。またその分散も大きくないので全員から高い評

Table 2 Questionnaire results on the effectiveness of the assistance system

\begin{tabular}{cc|c|c|c|c|c|c}
\hline \hline & \multirow{2}{*}{ Function } & Average & \multicolumn{6}{|c}{ Histogram } \\
\cline { 4 - 9 } & & Score & 5 & 4 & 3 & 2 & 1 \\
\hline (1) & Trajectory display & 4.29 & 2 & 5 & & & \\
\hline (2) & FSR display & 4.00 & 2 & 3 & 2 & & \\
\hline (3) & Search trace display & 4.14 & 3 & 3 & & & \\
\hline (4) & Display layout & 4.71 & 5 & 2 & & & \\
\hline (5) & Operation by mouse & 4.14 & 2 & 4 & 1 & & \\
\hline
\end{tabular}


価を得ていることがわかる．熟練者と未熟練者の回答を 比較しても際だった差異はみられなかった。

詳細に検討すると, 軌道や機器配置を可視化するイン タフェースに対する評価が相対的に高い.これは, 逆説 的に解釈すると, 従来のようなブラックボックス型イン タフェースに対するユーザの不満を表わしており，ユー ザに内部を見て理解したいという要望があることがわか る。また，FSR 表示インタフェースに対する評価が若干 低い理由は，やはりモデルと実システムとの不一致にあ ると考えられる. 誤差要因を解明してその補正を数式モ デルに盛り込むことによりガイダンスの精度を高めるこ とは今後の課題である。すでに垂直入射ブロックについ ては粒子間の相互作用による空間電荷効果の補正を検討 中である，提案したシステムがどのような場面で有効か という質問に対しては, 素人のオペレータのトレーニン グ, 調整前の事前シミュレーション, 最適值の大域的探 索に有効であり，局所的な微調整については従来方式が 良いとの意見が得られた。この理由としては，マウスと ロータリエンコーダの特性の差, ビーム電流表示の応答 性の差が考えられる。

\section{6. おわりに}

サイクロトロンの運転支援システムとして，オペレー タのもつメンタルモデルのイメージを可視化するヒュー マンインタフェースを開発した. 本稿では，まず，オぺ レータが五つのメンタルモデルをもつて操作にあたつて いることを明らかにした，つぎに，それらを図的に表現 して，未熟練者がメンタルモデルを生成するのを支援す るインタフェースとしてビーム軌道表示, FSR 表示, 操 作履歴表示を提案し実現した. 最後に, その効果を検証 するために，実システムにおいて調整時間の測定と操作 感覚のアンケート調査を行った. その結果, このインタ フェースにより，目標值を得るまでの時間は従来のシス テムに比べて $30 \%$ 以上減少することを確認した.また， アンケート調査の結果, これらの有効性についてすべて のオペレータから高い評価が得られた。

本システムの実装と評価から, 試行錯誤的な探索作業 を支援するインタフェースの一般的な設計指針として， (1) 内部状態をホワイトボックス化することによりオペ レータの深い理解を助けること,(2) 言語メッセージでは なく, 図的表現により直感的にガイダンス情報を与える こと, (3) 信頼できる数式モデルがあるなら, FSR 表示は 有効であること, (4) 視覚的フィードバックにより操作の 作用を常時確認できることをあげることができる.また， 設計に先だって人間のメンタルモデルを十分に分析する ことが人間とシステムの不整合を防ぐために重要である
ことも示した.

最後に, 本研究で常にご指導いただいた(財)パーソナ ル情報環境協会 FRIEND 21 研究セン夕長上滝致孝博士 に謝意を表する。

\section{参 考 文 献}

1) T. Okamura and T. Murakami : A Support System for Beam Adjustment of Cyclotron Based on Fuzzy Grading Model and Texture Display, 11th IFAC World Congress, IV, 57/62 (1990)

2) 岡村,村上：ファジィ関係に基づくサイクロトロンのビー ムパターン診断と調整ガイダンス,計測自動制御学会論文 集，26-8，870/877(1990)

3）岡村,村上：設定可能領域のリアルタイム表示によるサイ クロトロンの調整ガイダンス，計測自動制御学会論文集, 26-11，1305/1312(1990)

4) 岡村，村上：GMDHによるビーム軌道の近似モデルを用 いたサイクロトロンの調整ガイダンス，第 33 回自動制御 連合講演会，3073，493/494(1990)

5）岡村,村上：メンタルモデルに基づく機械システムの視覚 的な運転支援環境, 計測自動制御学会第 7 回ヒューマンイ ンタフェースシンポジウム論文集，517/522(1991)

6) W. F. S. Poehlman and J. W. Stark : Integrating Knowledge-Based Systems into Operations at the Mcmaster University FN Tandem Accelerator Laboratory, IEEE Transactions on Nuclear Science, NS-36-5, 1494/1498 (1989)

7). D. E. Schultz and P. A. Brown: The Development of an Expert System to Tune a Beam Line, Nucl. Instr. and Meth., A293, 486/490 (1990)

8）佐伯胖：インタフェースと認知工学, 情報処理, 30-1, 2/ 14(1989)

9) 佐伯, 西田: 認知科学の視点からみたヒューマンインタ フェース, 電学誌, 109-8, 645/647(1989)

10) D. A. Norman: Psychology of Everyday Things, Basic Books (1988), 野島久雄訳：誰のためのデザイン?, 新曜 社 (1990)

11）岡村,村上：サイクロトロンのビーム調整における調整手 順ルールの抽出, 第 27 回 SICE 学術講演会予稿集, 19/ 20(1988)

12）村上, 岡村：サイクロトロンビーム調整におけるパラメー 夕次元の縮約, 第 27 回 SICE 学術講演会予稿集, 21/ 22(1988)

13) B. Shneiderman : Direct manipulation; A Step Beyond Programming Language, IEEE Computer, 16-8, 57/69 (1983)

14) K. L. Brown, et al. : TRANSPORT ; A Computer Program for Designing Charged Particle Beam Transpot System, CERN, Geneva, Switzerland, Tech. Rep. CERN 80-04, 129/195 (1978)

15) C. J. Kost: The Computer Code "TRIWHEEL", TRIUMF, University of British Columbia, Canada

16）高山猛：AVF サイクロトロンの軌道解析プログラムに ついて，住友重機械技報，24-72，11/16(1976)

17) 大槻, 竹内, 有村, 森: マイクロワールド型 CAI と学習者 の意図の推定, 情報処理学会研究報告, CE-91-33, 137/ 144 (1991)

18) B. Shneiderman: Designing the User Interface (1987) Addison-Wesley, 東, 井関監訳：ユーザー・インタフェー スの設計，日径 BP 社(1987)

19) S. Okumura, et al. : Control System of JAERI Cyclotron, Proc. of 8th Symp. on Accelerator Science and Technology, 356/358 (1991) 
20）渡部，鈴木, 山田, 大塚：探索的デー夕解析入門, 17/18, 朝含書店 (1985)

21) M. Minsky: The Society of Mind, Simon \& Schuster (1986), 安西祐一朗訳: 心多社会, 216/217, 産業図書 (1990)

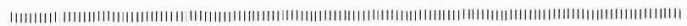

$$
\text { [著 者 紹介] }
$$

岡 村哲也 (正会員)

1980 年, 京都大学工学部電気第 2 学科卒 業. 同年住友重機械工業(株) 入社. 以来, システム技術研究所にて計算機制御，運転 支援システムの研究開発に従事. 情報処理 学会, 電子情報通信学会, IEEE などの会員 (工学博士).

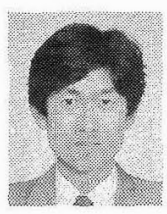

\section{上松敬}

1978 年, 長野県立長野工業高等学校電気 工学秘卒業. 同年日本原子力研究所入所. 82 年群馬大学工業短期大学部電気工学科 卒業. 大線量率電子線の線量測定技術, 工 業用 X 線発生装置の線量解析プログラム, 簡易型アラニン゙線量計測システム, 走查型 分光光度計の開発に従事.

\section{奥 村 進}

1989 年, 筑波大学理工学研究科修了. 同 年日本原子力研究所高崎研究所入所. サイ クロトロンの運転・技術開発に従事.

\section{荒川和夫}

1965 年, 長野県立長野工業高等学校電気 課程卒業. 同年日本原子力研究所入所. 負 イオン生成機構とイオン分子反応の研究, サイクロトロンの研究に従事し現在に至 る. 日本原子力学会, 日本化学会, 日本質 量分析学会, 加速器科学研究会などの会員 (工学博士). 学会の会員.
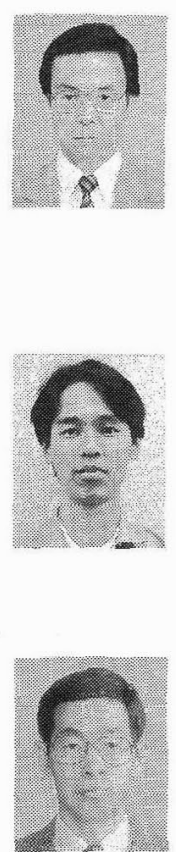